\title{
Verbal and Complex Modals in legal Cognitive Moves: A Cross-Linguistic Study of English and Persian
}

\author{
Mahin Koochaki
}

\author{
MA Translation Student \\ Mahin.koochaki@yahoo.com
}

Abbas Eslami Rasekh

Assistant Professor at Isfahan University

\section{Doi: 10.5901/mjss.2013.v4n4p111}

\section{Abstract}

This paper is a study of use and distribution of verbal and complex modals in two cognitive moves in legal deeds, namely provisionary clauses and qualification clauses (Bhatia, 1993). The focus is on modals in clauses in which legal entity/entities and legal actions are communicated as well as in clauses in which conditions surrounding legal actions are determined. The meanings, along with the frequency of occurrence, of modal words were detected and compared in provisionary and qualification clauses on the basis of Palmer's classification (2000). The findings of our comparisons revealed that indispensible components of provisionary clauses in the English data were deontic modalities shall and may. Persian counterparts i.e. بايد (bAyad: must) and توانستن (tavanestan: may do/be allowed to do) were identified as equivalents; however, بايد (bAyad: must) displayed a lower frequency of use. The substitutes of such a low frequency of use were (a) simple present and (2) simple future.

Keywords: Deontic modality (DM), dynamic modality (DyM), epistemic modality (EM), provisionary clause (PC), qualification clause (QC)

\section{Introduction}

Language devices exist which indicate such modal meanings as obligation, permission, willingness, necessity, speculation, confidence, etc. The complex modal be able to, the verb want, and phrases such as be going to, epistemic adverbs conveying speculation and certainty and finite-noun complement clauses such as the certainty that ... are instances of such meanings. Apart from these, in English and Persian legal texts, verbal and complex modals are assigned to intensify and decrease the extent of obligation, certainty and willingness. They are applied for designating the way legal entity/entities are to implement a legal action and the way conditions result in the implemented action. For instance, in (1) would displays probability as to the condition i.e. to release the prisoner unconditionally and shall attributes to obligation as to the legal action i.e. to release on license;

(1) "Where, apart from this subsection, the prisoner would be released unconditionally-

(a) he shall be released on licence; and ..." (Section 44 of Crime \& Disorder Act 1998)

The work presented in this article is an attempt to answer following questions. (1) Which verbal and complex modals are used with respect to legal entities and legal actions and which ones in relation with conditions or matters surrounding legal actions? (2) Are there any verbal and complex modals which are used in collaboration with both legal actions and conditions?

To fulfill the aim, the current paper considers followings in PCs and QCs: (1) modal options conveying confidence and probability, (2) those attributing to obligation and permission and (3) those containing willingness and necessity arising from internal condition of the person/action concerned. These will be set out in detail by separate tables. Then, the discussion section reveals the findings about what above meaning components are assigned to PCs and QCs and to what extent. Last, the general findings in relation with the translational concerns will be summarized in conclusion. 


\section{Methodology}

This study evaluates the way modalities are arranged in legal documents as to collaboration on the one hand with legal entities and actions and on the other hand with demanding conditions. The data selected for this study are Crime \& Disorder Act 1998, Theft Act 1968, Offences against the Person Act 1861, and Islamic Punishment Act 2012. To accomplish the objective, meaning components of complex and verbal modals, assigned in the selected data to evoke the modality point of view, were detected on the basis of Palmer's definition of modalities (2000) as indicated below;

A. Epistemic Modality (EM): The speaker indicates that he is not presenting what he is saying as a fact but he reports them based on the speculation and/or deduction. The inferences mentioned are associated with notions of possibility and necessity. So, EMs express possible judgment (e.g. may), the only possible judgment (e.g. must) or reasonable judgment based on known facts (e.g. will). They can also have tentative forms to convey the meaning of objective judgment.

B. Deontic Modality (DM): The speaker commits others or permits them to do the action concerned. As with EMs, they are in relation with notions of possibility and necessity. In the case that an action is to be done inevitably, DMs take a strong form (e.g. must). Where suggestion rather than mere permission is offered, they take the weak form (e.g. might). Like EMs, they can take tentative forms to convey the objective obligation such as ought to and should or to offer suggestion such as might and could.

C. Dynamic Modality (DyM): As indicated by Taleghani (2008: 22), DyMs relate to the ability or willingness, originating from internal factors of the individual concerned. In other words, no obligation is imposed on the person in order to do the considered action but what is required as to his/her internal condition. The same could be suggested as regard what is required to be done for the action concerned, resulting from its internal requirements.

In addition, in respect of the meanings of Persian verbal and complex modals, Amid Persian Dictionary (2010) and Online Persian Dictionaries (www.vajehyab.ir) were utilized. Then, English and Persian modalities were again grouped in terms of their occurrence in two cognitive moves i.e. PCs and QCs on the basis of Bhatia's classification (1993: 115);

A. Provisionary clauses(PCs) describe party/parties to a given legal situation and legal action(s) enforced for them.

B. Qualification clauses (QCs) designate (I) conditions specified for the legal entity/entities and actions, being indicated by where, if, unless, before, after, etc. (II) manners in which the given legal entity exercises a particular function, being emphasized by verb strings and modal strings, or (III) inter-intra textual references which are displayed in documents by clauses such as "as mentioned in paragraph above".

\section{Data analysis}

\subsection{Epistemic modality}

Table below cites options used in the English data as regards the epistemic notion. Of those evoking certainty, shall was most frequently distributed. Wherever it was required to communicate the certainty about cases where the offence was committed shall came into existence. This certainty resulted in formulating relevant legal actions. This is obvious in (2);

(2) "Whosoever shall, by any means whatsoever, attempt to choke, suffocate or strangle any other person ..." (Section 21 of Offences against the Person Act 1861)

In a very few cases, will was used. Unlike shall, it was in one case in collaboration with the legal action concerned. Moreover, in two cases, the confident prediction was communicated in relation with the past event.

Probability, as indicated below, was offered as follows: logical possibility, a definite degree of possibility as to occurring events, possibility of something but not very likely (Swan, 1995:335), the imagined result of an event and probability with respect to what happened in the past. They all occurred, in most cases, only in QCs. Therefore, it is obvious that they have acted as the focus of matters by which the legal actions concerned are enforced. However, will and would in one and two cases respectively constituted the components of PCs as well. 


\section{Table 1}

\begin{tabular}{|c|l|c|c|}
\hline & \multirow{2}{*}{ Meaning } & \multicolumn{2}{|c|}{ Frequency of occurrence } \\
\cline { 3 - 4 } & & PC & QC \\
\hline Shall & Certainty or confidence about present or future situations & 0 & 40 \\
\hline will & Certainty or confidence about present or future situations & 1 & 9 \\
\hline $\begin{array}{c}\text { Will have past } \\
\text { participle }\end{array}$ & Giving a prediction for a future activity or event & 0 & 2 \\
\hline Ought to & $\begin{array}{l}\text { guessing or concluding that something is probable because it } \\
\text { is logical or normal }\end{array}$ & 0 & 1 \\
\hline may & Suggesting a more definite possibility than that of might & 0 & 41 \\
\hline might & Suggesting a smaller chance & 0 & 2 \\
\hline $\begin{array}{c}\text { May/might have } \\
\text { past participle }\end{array}$ & $\begin{array}{l}\text { Indicating that it is possible something happened or was true } \\
\text { in the past }\end{array}$ & 0 & 2 \\
\hline could & Attributing to logical possibility & 0 & 1 \\
\hline $\begin{array}{c}\text { Could have past } \\
\text { participle }\end{array}$ & $\begin{array}{l}\text { Guessing or speculating about what has happened, whether } \\
\text { things have happened, etc. }\end{array}$ & 0 & 3 \\
\hline would & Referring to result of an event that somebody imagine & 2 & 45 \\
\hline $\begin{array}{c}\text { Would have past } \\
\text { participle }\end{array}$ & Showing that something would happen in the past & 0 & 23 \\
\hline
\end{tabular}

In the Persian data, two options evoked epistemic point of view. They both attributed only to the probability and both delineated some aspects regarded as condition as in (3) and (4).

\section{(3) ... مكر اينكه به نظر قاضي احراز شر ايط در 10 روز ممكن نباشد}

Magar in-ke be nazar-e ghazi ehraz-e sharayetdar dah roozmomkenna-bashad.

Unless this-that with view-of judge gain-of condition in ten day possible Negative-present-become

... Unless to the discernment of the judge, the requirements are not possible to fulfill within 10 days.

Agar ehtemAl-e An bashadke ...

$$
\text { (4) اكر احتمال آن باشد كه ... }
$$

If probable-of it that ...

If it is probable that ...

In a few cases such as (5), امكان داشتن/ممكن بودن (emkAndAshtan/ mumkenbudan: to have a possibility/probability) signified probability as to the legal action concerned too.$$
\text { (5) تعليق مجازات بار رعايت مقررات مندرج در تعويق صدور حكم ممكن است به صورت ساده يا مراقبتي باشد }
$$$$
\text { Taligh-e mojazatbara-ayatemoghararet-e mondarajdartaavigh-e sodour-e hokmmomkenast be }
$$
sooratesadeyamoraghebatibashad.

Postponement-of punishment with observe law mention-past in suspend issuance-of sentence possible to simple or caring $3^{\text {rd }}$-singular-present-be.

The suspension of the sentence, if regulations mentioned with respect to the suspension of the sentence are obeyed, is possible to be simple or complex.
}

\section{Table 2}

\begin{tabular}{|c|c|c|c|}
\hline & \multirow[t]{2}{*}{ Meaning } & \multicolumn{2}{|c|}{$\begin{array}{l}\text { Frequency of } \\
\text { occurrence }\end{array}$} \\
\hline & & PC & QC \\
\hline $\begin{array}{c}\text { (مكان داشتن/ممكن بودن: } \\
\text { (emkAndAshtan/ mumkenbudan: to have a possibility/probability) }\end{array}$ & $\begin{array}{l}\text { Showing attitude toward the truth } \\
\text { value of the sentence }\end{array}$ & 4 & 28 \\
\hline $\begin{array}{c}\text { احتمال داشتن } \\
\text { (ehtemAldAshtan: to have probability) }\end{array}$ & $\begin{array}{l}\text { Showing probability about what } \\
\text { would happen }\end{array}$ & 0 & 2 \\
\hline
\end{tabular}




\subsection{Deontic modality}

In the English data, some verbal modals indicated different extents of obligation i.e. absolute obligation, tentative obligation and strong advice. Wherever the legal entity concerned was obliged to do a particular legal action, shall was deployed. Accordingly, it has been predominantly observed in PCs. In the case that the tentative obligation was required to be communicated, should entered into action. Its occurrence in QCs implied that the tentative obligation acted as conditions. In PCs, its deontic focus was shifted to some extent by shall as shown in (6). This could be outlined as follows: The Board is obliged to order whether to release or not to release the prisoner concerned;

(6) "Where the case of a prisoner to whom this section applies is referred to the Parole Board under this section or section 17(3) of this Act, the Board shall, if it is satisfied that it is no longer necessary for the protection of the public from serious harm that the prisoner should be confined (but not otherwise), direct that he should be released." (Section 88 of Crime \& Disorder Act 1998)

If the strong advice (required as much as to be regarded as order) was intended to be given, must came into existence. It was only deployed as follows: if condition $X$ occurs, then the legal entity concerned is advised to do the legal action $Y$.

\section{Table 3}

\begin{tabular}{|l|l|l|l|}
\hline \multirow{2}{*}{} & \multirow{2}{*}{ Meaning } & \multicolumn{2}{|l|}{ Frequency of occurrence } \\
\cline { 3 - 4 } & & PC & QC \\
\hline Shall & Absolute obligation & 836 & 14 \\
\hline Should & Tentative obligation & 9 & 1 \\
\hline Must & Giving strong advice and orders & 6 & 0 \\
\hline
\end{tabular}

In the Persian data,the only verbal modal which communicated the meaning of obligation was بايد (bayad: must). It occurred where someone other than authorities was to do required legal actions as in (7). However, in a few cases, authorities as well were forced to perform actions by بايد (bayad: must).

$$
\text { (7) مجرم بايد مالي را كه در اثر ارتكاب جرم تحصيل كرده است ... به صاحبش رد كند. }
$$

MojrembAyadmalirakedarasar-e ertekab-e jormtahsilkard-e ast ... be sahebash rad konad. Offender should property that by commit offence gain-past to the owner return $3^{\text {rd }}$ person-present. The offender should return the property acquired by committing the offence to its owner.

Such a focus of meaning was often construed in PCs. In most other cases such as (8), simple present and future communicated duties which were required to be done by authorities. They were deployed to a large extent in PCs. In this regard, they were approximately equivalent to shall.

Modat-e habs az rouzi Aghaz mi-shavad ke ...

$$
\text { (8) مدت حبس از روزي آغاز ميشود كه ... }
$$

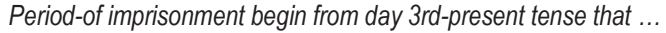

The period of imprisonment commences from the day when ...

Complex modals i.e. مكلف بودن (MokalafBudan: to be obliged to do something), موظف بودن (movazafBudan: to have responsibility) and مسئول بودن (MasoulBudan/MovazafBudan: to have responsibility) were used as well to denote obligation. They, as illustrated in table below and as indicated in examples 9-11, are very similar in meaning. They all were associated with legal actions.

Shakhsikevasiledarekhtiyar-e ouboudehmokalafast ...

$$
\text { (9) شخصي كه وسيله در اختيار و تصرف او بوده ... مكلف است... }
$$

Person who motorcycle in possession his have-perfect oblige $3^{\text {rd }}$-past ...

The person who has taken the possession of motorcycle is obliged to ... 
Dadgahmovazaf be barresivatahghighast.

$$
\text { (10) دادكاه موظف به بررسي و تحقيق است. }
$$

Court oblige to examine and investigate $3^{\text {rd }}$-present.

The court is obliged to conduct the investigation.

$$
\text { يك مسئول نصف ديه ي رانتده مقابل و سرنشينان هر دو وسيله ي نقليه است. }
$$

Haryekmasoule-of nesfediyey-e ranandey-e moghabelvasarneshinan-e har do vasiley-e naghliyeast.

Each one responsible half-of blood money-of driver other and occupants of both vehicles 3 rd-present-tense.

Each one is responsible to pay half of blood money to the other driver and to occupants of both automobiles.

However, in a few cases, they were related to demanding conditions.

As for indicating that $\mathrm{sb}$ was expected to do or not to do a particular action in compliance with what was considered morally accurate, ندوب زى (JAyezboodan: to be permissible) came into existence. It related to the legal actions as much as to the conditions. For example, consider (12);

Bedoon-e pardakhte An, ejray-e ghesasjayeznist.

$$
\text { (12) ... بدون بِرداخت آن [ ديه] ، اجراي قصاص جايز نيست. }
$$

Without payment of it [blood-money], retaliation permit Negative-present.

\begin{tabular}{|c|c|c|c|}
\hline & & Freque & currence \\
\hline & & PC & QC \\
\hline Simple present and future & $\begin{array}{l}\text { Showing that authorities are obliged to do the action } \\
\text { ordered }\end{array}$ & 700 & 0 \\
\hline $\begin{array}{c}\text { جايز بودن } \\
\text { (JayezBudan: to be } \\
\text { permissible) }\end{array}$ & $\begin{array}{l}\text { showing that the mentioned action is expected to be } \\
\text { done because of moral considerations }\end{array}$ & 3 & 3 \\
\hline $\begin{array}{c}\text { (bAyad: must) } \\
\text { (bAائ }\end{array}$ & having obligation to do some action & 103 & 3 \\
\hline $\begin{array}{c}\text { (MokalafBudan: to be obliged } \\
\text { to do something) }\end{array}$ & Showing that someone has obligation to do something & 13 & 1 \\
\hline $\begin{array}{c}\text { موظف بودن' } \\
\text { (MasoulBudan/MovazafBuda } \\
\text { n: to have responsibility }\end{array}$ & $\begin{array}{l}\text { Showing that someone has responsibility to do } \\
\text { something }\end{array}$ & 20 & 1 \\
\hline $\begin{array}{l}\text { (Masoulbudan: to be } \\
\text { responsible) }\end{array}$ & $\begin{array}{l}\text { Showing that someone has responsibility to do } \\
\text { something }\end{array}$ & 9 & 2 \\
\hline
\end{tabular}

Without paying blood money, the retaliation is not permitted.

\section{Table 4}

English documents contained modals which conveyed permission. They were as follows;

(A) In the case that permitting someone to do the considered action was demanded, may was the required option. It approximately tripled in PCs as contrasted with QCs. In other words, the legal entity was often allowed to do a particular action and sometimes the permission given to someone acted as the requirement through which the intended legal action was done.

(B) The focus on the positive suggestion was provided as well. To denote such a meaning, might was minimally deployed only in QCs. This indicated that giving suggestion, in a very few cases, constituted conditions affecting legal situations.

(C) Refusal of permission was met by can't, being assigned to PCs. This emphasizes that refusing to give permission to someone could not occur unless can't appears beside the legal entity and the legal action. 
Table 5

\begin{tabular}{|l|l|c|c|}
\hline \multirow{2}{*}{} & \multirow{2}{*}{ Meaning } & \multicolumn{2}{|c|}{ Frequency of occurrence } \\
\cline { 3 - 4 } & & PC & QC \\
\hline May & Mere permission & 194 & 51 \\
\hline might & A positive suggestion & 0 & 2 \\
\hline Can't & to refuse permission & 4 & 0 \\
\hline
\end{tabular}

One verbal modal and two complex modals were provided in the Persian data as to the permission. Their emphasis of meaning was as follows. (1) Someone (of authorities as well as of other persons) was permitted to do the action considered. This was always associated with legal actions, except in the one case. (2) Someone was permitted to do a particular action against the other party inflicting his/her harm. This was often in relation with legal actions and sometimes with conditions. (3) No person was allowed to leave something in places where it would cause harm. In respect of cognitive moves, it was required in QCs, on which some legal actions were founded. (4) The person addressed was allowed to do what he/she had requested, which participated with components of only one PC.

\section{Table 6}

\begin{tabular}{|c|c|c|c|c|}
\hline & \multirow{2}{*}{ Meaning } & \multirow{2}{*}{$\begin{array}{l}\text { Further Meaning with respect to } \\
\text { Occurrence Environment }\end{array}$} & \multicolumn{2}{|c|}{$\begin{array}{c}\text { Frequency of } \\
\text { occurrence }\end{array}$} \\
\hline & & & $P C$ & $Q C$ \\
\hline $\begin{array}{c}\text { توانستن } \\
\text { (tavAnestan: may/to be allowed) }\end{array}$ & $\begin{array}{l}\text { giving permission to somebody in } \\
\text { order to do something }\end{array}$ & - & 115 & 1 \\
\hline $\begin{array}{c}\text { حق داشتن } \\
\text { (HaghdAshtan: to have right) }\end{array}$ & $\begin{array}{l}\text { Emphasizing that someone has the } \\
\text { right to do something }\end{array}$ & $\begin{array}{l}\text { the party against whom the other } \\
\text { party inflicted a harm is allowed to } \\
\text { do the regulated legal action }\end{array}$ & 15 & 4 \\
\hline $\begin{array}{c}\text { (MojAzBudan/mojAzNabudan: to } \\
\text { be/not to be permissible) }\end{array}$ & $\begin{array}{l}\text { Showing that something is/is not } \\
\text { permitted }\end{array}$ & $\begin{array}{l}\text { PC: the person addressed is } \\
\text { allowed to do what he/she was } \\
\text { requested } \\
\text { QC: someone (authority or other } \\
\text { persons)is not allowed to leave } \\
\text { something in the specified places } \\
\text { where it would cause harm }\end{array}$ & 1 & 4 \\
\hline
\end{tabular}

\subsection{Dynamic Modalities}

As regards indication of choices and necessities someone had in relation to his/her internal conditions, following verbal modals were used in English documents;

A. Can, as defined by Swan (1995:122), suggests choices and opportunities somebody has. Furthermore, as asserted by Taleghani (2008:22), can refers to the willingness or ability originating from internal factors of the person concerned. Accordingly, the way it was treated in the analyzed data was "whenever addressees were to be informed that they had choices related to the relevant legal situations and they were to take one of them in accordance with their internal factors, can entered into action". Such delineation was offered in PCs, except in the one case.

B. Apart from frequently-distributed modalities used in the analyzed data, the section 8 of Crime \& Disorder Act 1998 contains once-occurred modal i.e. need, which as displayed below, signifies an immediate necessity. It applied only to the QC, communicating information as to the manner in which the legal entity concerned was allowed to do the given legal action i.e. include;

(13) A parenting order may, but need not, include such a requirement as is mentioned in subsection (4) (b) above in any case where such an order has been made in respect of the parent on a previous occasion. 
Table 7

\begin{tabular}{|l|l|c|c|}
\hline \multirow{2}{*}{} & \multirow{2}{*}{ Meaning } & \multicolumn{2}{|c|}{ Frequency of occurrence } \\
\cline { 3 - 4 } & & PC & QC \\
\hline \multirow{2}{*}{ can } & $\begin{array}{l}\text { ability or willingness originating from internal } \\
\text { factors of the individual concerned }\end{array}$ & 1 & 4 \\
\hline need & immediate necessity & 0 & 1 \\
\hline
\end{tabular}

The Persian data contained a number of complex modals which had the deontic notion. The meanings carried by them were as follows;

(A) احتياج داشتن (ehtiyAjdashtan: need to have) had the sense of what someone concerned needed to have on the basis of what was related to him/her. In its only occurrence, it was included in the QC. For instance, (14) could be indicated as such: if the person concerned needs to have the emergent help, then the legal action $Y$ is required to be done.

HargahmasdoomehtiyAj be komak-e foridasht-e va ...

$$
\text { (14) هركاه مصدوماحتياج به كمك فوري داشته و ... }
$$

Whenever injured need to help emergent $3^{\text {rd }}$-singular-present and ...

If the injured needs an emergent help and ...

(B) More strong forms i.e. لازم بودن (IAzembudan: to be necessary) and الزامى بودن (elzAmibudan: to be necessary) were used in order to describe cases in which some obligations were imposed on the considered person. Such a necessity was resulted from his or her internal requirement(s). These two modals communicated such a meaning in collaboration with legal entities and legal actions (example 15) as well as with demanding conditions (example 16);

$$
\text { (15) كه در اين صورت، حداقل شهادت سه مرد و دو زن عادل لازم است }
$$

Kedar in sourat had-e aghalshahadat-e se mardva do zan-e adellAzemast.

That subject in this case at least witness of three man and two woman just necessary 3pl-present In this case, at least three just men and two women are necessary to witness.

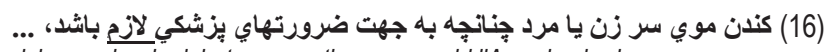

Kandanemoy-e sar-e zanyamardchenanch-e be jahat-e zarorathay-e pezeshkilAzembashad, ...

Cutting hair-of head-of woman and man if for emergency-of medical necessary present-be

To cut hair of man or woman, if necessary for medical emergency, ....

(C) ضرورى بودن (zarouribudan: to be essential) indicated that a particular action was essential to be done because the internal factor relevant to characteristics of the action itself or to the person concerned necessitated it. Minimally occurring, it was deployed only in PCs. As a matter of fact, it was used to specify the following: if the condition A occurs, then it is or as in (17) is not essential to do B.

Dar mavared-e fori akhz-e rezayat zarouri na-khahad boud.

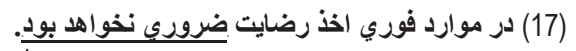

(D) كافى بودن (kAfibudan: to be sufficient) was deployed wherever the following was required: the person concerned is sufficient to do the action A if the condition B exists, without exercising any further function or implementing any further action. This is obvious in (18).

Hargah elm-e vey be anch-e bar An sogandyad mi-konad kafiast.

$$
\text { (18) هركاه ....، علم وى به آتجُه بر آن سوكند باد ميكند كافى است. }
$$

Whenever ..., awareness his to what on which oath take sufficient $3^{\text {rd }}$ singular-present.

If ..., his awareness of what he takes oath on is sufficient. 
In (19), it denoted the same meaning but in the QC: if the property $A$ is not sufficient to make up for $X$, then the action $B$ is to be done.

Hargahtarakey-e oubaray-e adAy-e doyoonoukafina-bashad, ....

$$
\text { (19) هركاهتركه ي او براي اداي ديون او كافي نباشد، ... }
$$

Whenever property-of his for pay debt-of his sufficient Negative-present

If his property is not sufficient for paying his debts, ....

(A) مستلزم بودن (mostalzembudan: required something to be done) signified that the action A was required to be done before the intended action $B$ in order to comply with the internal condition of the action $B$. This indication was received both in PCs (example 20) and QCs (example 21);

(20) منع از رانتدكى و تصدى وسيله ى نقليه ى موتورى مستلزم ابطال كواهينامه و ممنوعيت از درخواست مجدد است. Man az ranandegi va tasaddiy-e vasileye naghliyey-e motori mostalzem-e ebtal-e govahinameh va mamnouiyat az darkhast-e mojadad ast.

Prohibition-of drive and have-of vehicle move motorcycle require cancellation-of card and prohibition-of request again present-tense.

The prohibition of driving and possessing motorcycle needs the annulation of the driving license and the prohibition of another request for taking license.

$$
\text { (21) اكر قصاص مستلزم بِرداخت فاضل ديه از سوي ولي دم به قاتل باشد، .... }
$$

Agar ghesasmostalzemepardakht-e fazel-e diyeazsouy-e valiy-e dam be ghatelbashad ....

If retaliation require payment of extra-of blood money from relatives of murdered to murder ...

If retaliation needs relatives of the murdered to pay extra blood money, ...

(B) اختيار داشتن (ekhtiyArdAshtan: to have freedom) attributed to the fact that it was depended on the relevant person to do or not to do something. In its only occurrence done in the $\mathrm{QC}$, it was described that the person in charge could decide to do or not to do the action mentioned, without any obligation imposed by others or by regulations. مختار بودن (mokhtArbudan: to have freedom) and مخير بودن (mokhayerbudan: to have freedom) were taken as derived forms of اختيار داشتن (ekhtiyArdAshtan: to have freedom). They participated with legal actions as (22) as well as with conditions as (23).

$$
\text { هركاه ....، مجني عليه يا اولياي دم در مراجعه به هر يك و اخذ ديه از آنها مخيرند. }
$$

Hargah ..., mojniyonelayhyaoliyay-e dam darmoraje be haryekvaakhzdiyehazanhamokhayerand. Whenever ..., victim or relatives in refer to each one and collection-of blood money freedom has-present. If..., the victim of an offence or his relatives can ask for the blood money.

... kefardhin-e ertekab-e jormaghelbaleghvamokhtArbashad.

$$
\text { 2. كه فرد حين ارتكاب جرم، عاقل، بالغ و مختار باشد }
$$

... That person, while commit offence, wise, mature and independent $3^{\text {rd }}$-present.

... Where the person concerned, at the time of committing offence, is wise, mature and independent.

The only Persian verbal modal which could be regarded as DyM was توانستن (tavAnestan: can/ to be able). It was mostly offered in the negative form. With respect to its only distribution in QCs, it denoted that if the person concerned was or was not able to do the relevant action as the result of his/her own factors, then the action/actions formulated was/were to be put into action.

$$
\text { 24) هر كس نتو اندصحت آن اسناد را تاييد كند، به حبس و ... محكوم خواهد شد. }
$$

Harkasna-tavAnadsehhat-e An asnad-rata'yeedkonad, be habsva ... mahkoomkhahad shod.

Whoever ... can-Negative authenticity-of that document $3^{\text {rd }}$-person-present, to imprisonment sentence $3^{\text {rd }}$-singular-

future.

Whosoever ... cannot prove the authenticityof these documents shall be sentenced to imprisonment and ... 


\section{Table 8}

\begin{tabular}{|c|c|c|c|}
\hline & \multirow{2}{*}{ Meaning } & \multicolumn{2}{|c|}{ Frequency of Occurrence } \\
\hline & & PC & QC \\
\hline $\begin{array}{c}\text { احتياج داشتنت } \\
\text { (ehtiyAjdAshtan: need to } \\
\text { have) }\end{array}$ & $\begin{array}{l}\text { Indicating Internal and external obligation } \\
\text { originated from internal factors }\end{array}$ & 0 & 1 \\
\hline $\begin{array}{c}\text { لازم بودن/الزامى بودنن/ZAmiBudan: } \\
\text { (LAzembudan/elzAmidy) } \\
\text { to be necessary) }\end{array}$ & $\begin{array}{l}\text { To denote that Internal and external obligation is } \\
\text { imposed on sb because of internal factors }\end{array}$ & 17 & 14 \\
\hline $\begin{array}{c}\text { ضرورى بودن } \\
\text { (zarouriBudan: to be } \\
\text { essential) }\end{array}$ & Showing that it is essential to someone to do sth & 2 & 0 \\
\hline $\begin{array}{c}\text { (KAfiBudan: to be sufficient to } \\
\text { do sth) }\end{array}$ & $\begin{array}{l}\text { Showing that it is sufficient for someone in order to } \\
\text { do a considered action }\end{array}$ & 3 & 1 \\
\hline $\begin{array}{l}\text { مستلزم بودنن } \\
\text { (MostalzemBudan:be } \\
\text { required something to be } \\
\text { done) }\end{array}$ & $\begin{array}{l}\text { Showing that the action } A \text { is required to be done } \\
\text { before action } B \text { because of internal requirement of } \\
\text { the action } B\end{array}$ & 3 & 7 \\
\hline $\begin{array}{c}\text { اختيار داشتن/مختّار بودن/مخيرن } \\
\text { (EkhtiyArDashtan/MokhtArBu } \\
\text { dan/mokhayerbudan: to have } \\
\text { freedom) }\end{array}$ & $\begin{array}{l}\text { Showing that somebody has freedom to do or not } \\
\text { to do the action concerned }\end{array}$ & 3 & 1 \\
\hline $\begin{array}{c}\text { توانستن } \\
\text { (TavAnestan: can/to be able) }\end{array}$ & $\begin{array}{l}\text { Suggesting what someone can do on the basis of } \\
\text { his or her internal conditions }\end{array}$ & 0 & 13 \\
\hline
\end{tabular}

\section{Discussion}

The analysis of English data revealed that leading modalities were shall and may which abundantly denoted absolute obligation and permission respectively. The former has been observed to a large extent in PCs and scarcely in QCs. This indicated absolute obligation as the participant of the legal action. However, in a very few cases, they were associated with conditions surrounding legal situations. The latter was deployed in PCs, however not with equally abundant frequency of use as that of shall, as well as in QCs. In a very simple word, it often functioned as what the legal entity was permitted to do and sometimes it was offered as the component of the condition out of which the legal action concerned was to be implemented. Other modals were distinct from shall and may in terms of meaning and their extent of occurrence. In this regard, must, might andcan't conveyed strong advice, suggestion and refusal ofpermission respectively. As indicated below, PCs and QCs contained these options to a very small extent as compared with shall and may.

\section{Figure 1}

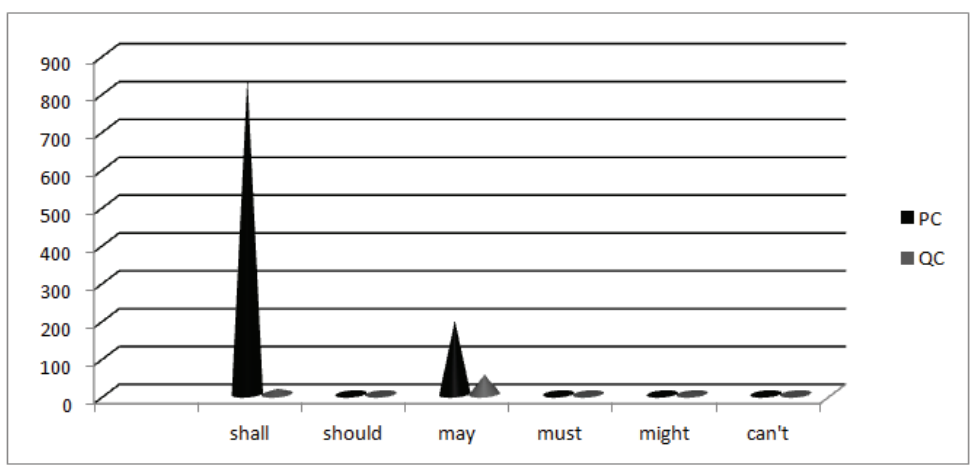


In the Persian data, complex modals entered into action, along with one verbal modal, in order to convey obligation. بايد (bAyad: must), as the option that is morphologically equivalent to shall in terms of obligation, occurred where parties to legal action other than authorities were obliged to perform formulated actions. This indication was often given in PCs. As regards the extent of distribution, the simple present and the simple future were equivalent to shall. They referred to duties assigned to authorities. In addition, مسئول بودن (masoulbudan:to be responsible), موظف بودن (movazafbudan: to have responsibility) and مكلف بودن (mokalafbudan: to be obliged to do sth) carried the meaning of obligation imposed on authorities or persons in charge. They, too, were often included in PCs. Indeed, obligations, in most cases, were offered in respect of legal actions.

In respect of permission, تو انستن (tavAnestan:may/to be allowed) was abundantly distributed in PCs and only once in the QC. It was used whenever someone was permitted to do the action mentioned and whenever the action concerned was subject to the related permission. Different complex modals were also deployed, attributing to very similar meaning. They were, similarly, often indicated in PCs. This could be formulated as such: if condition X happens, then Person A is permitted to do Y. The following diagram illustrates the extent to which Persian DMs applied to the cognitive moves;

Figure 2

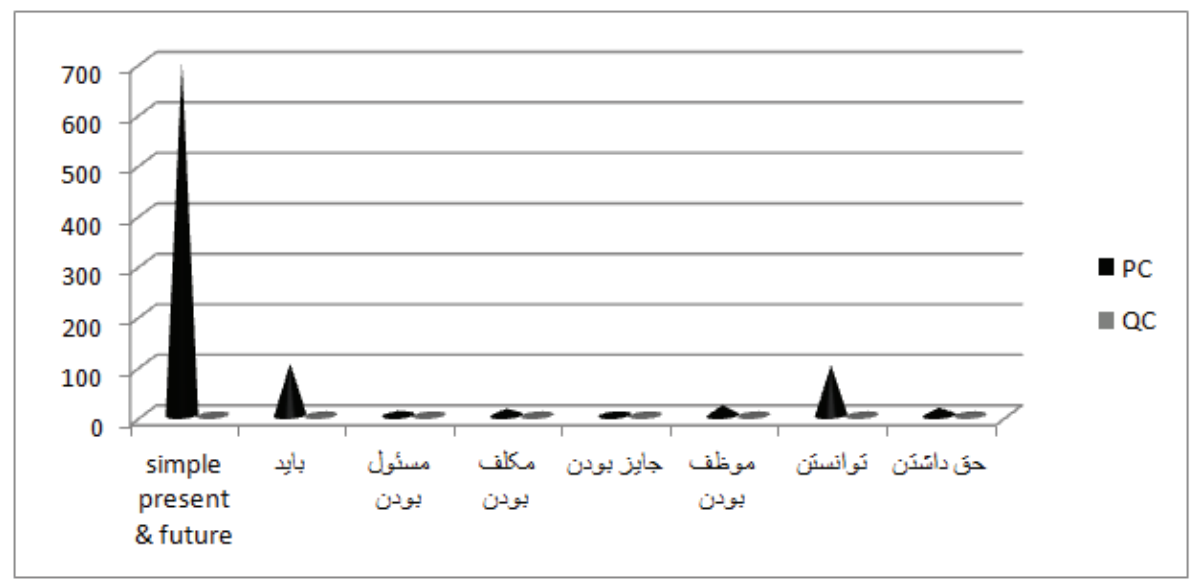

Besides, some modal options specified confidence and probability in the English data. Their minimal occurrence was obvious as contrasted with DMs especially shall and may. They acted in QCs, except in a few cases where they functioned as the participant of legal actions. In other words, confidence and probability was not as much legal-action oriented as to be construed highly as the component beside legal actions. Instead, they were often added to conditions out of which legal actions were performed.

In the Persian data, however, there were only two options which could be considered as epistemic. They were distributed in both cognitive moves. Their occurrence in PCs could be discussed two-fold: (1) conditions were as much specified as that EMs were allowed to enter into PCs and (2) they were not as much legal-action oriented as to be distributed in PCs at least to the same extent as in QCs.

Willingness and necessity to do a particular action were considered as well. This is a further indication as to the fact that any notion considered significant is included in legal deeds. However, they were low in frequency. Can, as the option which denoted willingness, belonged to the required conditions. But in one case, it showed the concern about the legal action considered. This demonstrated that it often communicated information as to the condition affecting the legal situation concerned.

In the Persian corpora, a more number of DyMs were distributed. Most of them attributed to the necessity and a few to the willingness. They exercised their functions in both cognitive moves. The exceptions to this distribution were (احتياج داشتن (ehtiyAjdashtan: need to have) and توانس (tavAnestan: can/ to be able) which were used only in QCs and ضرورى بودن (zarouribudan: to be essential) which only became available to PCs. Nevertheless, as options denoting necessity in one hand and those conveying willingness in the other hand were so much similar in meaning, it could be pointed out that necessity and willingness were communicated in relation with both legal actions and demanding conditions. 
Concerning verbal and complex modals used in both PCs and QCs, the followings were detected: (1) EMs will, would, مكان داشتّن/مدكن بودن(emkAnDashtan/ mumkenbudan: to have a possibility/probability), (2) DMs shall, should

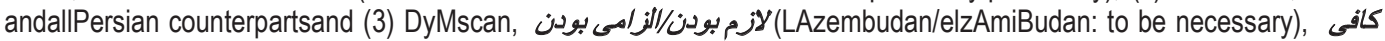

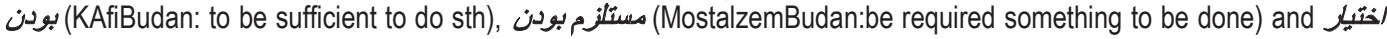
(EkhtiyArdAshtan/MokhtArBudan/mokhayerbudan: to have freedom). However, the frequency of occurrence in PCs and QCs related to each type of modalities differs from each other i.e. EMs and DyMs were distributed mostly in QCs and DMs mostly in PCs. This showed that EMs often offer modal notions in relation with conditions, so did DyMs. And, DMs often were associated with the legal actions.

\section{Conclusion}

Analysis and discussion of the data collected in this study displayed that English and Persian modals were distributed with large extent of similarity in PCs and QCs. In a very simple word, EMs and DyMs occurred mostly in QCs and DMs mostly in PCs. The findings of this study could put forward suggestions for selecting translation options as follows. First,in order to convey the meaning of absolute obligation, shall is to be deployed in English. The same in Persian is to be offered on the basis of the followings:(1)In the case that authorities are obliged to perform the action concerned, simple present and simple future are used, (2) otherwise, complex modals indicated in Table 4 are utilized and (3)Where persons other than authorities are to exercise the function concerned, بايد (bAyad: must) comes into existence. Second, other English options as to obligation delineate tentative obligation and strong advice. They are coded by should and must respectively. Other focus on obligation in Persian is offered by complex modals, to the large extent of similarity in meaning. Third, three modal options have the sense of permission in English Acts. They should be selected on the basis of the fact that whether mere permission, positive suggestion or refusal of permission is to be communicated. In the Persian deeds, similarly, three DMs exist. They bear very similarity in meaning. However, they are distinct in respect of the occurrence environment, which were indicated in table 6.

Last but not least, since epistemic notions play a significant role in specifying demanding conditions out of which legal actions are to be formulated, their equivalents are to be selected to a large extent of caution. In addition, the more number of English EMs than those of Persian cause more concern for offering accurate equivalents. Table 1 could suggest clues in this regard.

To sum up, all modal types are used in both English and Persian legal texts analyzed in this study. No matter in what cognitive move they are distributed and to what extent, each one communicates some information associated with legal actions and/or with conditions. Accordingly, their specification of meaning should be considered in translation as much precise as possible. Otherwise, the misunderstanding arises as to legal decisions that are to be made on the basis of translated legal texts.

\section{References}

Amid, H. (2010). Persian Dictionary. Iran: RaheRoshd.

Bhatia, V.K. (1993). Analyzing Genre: Language Use in Professional Settings. USA: Longman Publishing.

Crime \& Disorder Act (1998). [Online] Available: www.thamesvalley.police.uk (June 22, 2012).

Islamic Punishment Act (2012). [Online] Available: www. Iran-eng.com/ (June 22, 2012).

Offences against the Person Act (1861). [Online] Available: www.lawteacher.net (June 22, 2012).

Online Persian Dictionaries. [Online] Available:www.vajehyab.ir (June 30, 2012).

Palmer, F.R. (2000). Mood and Modality. USA: Cambridge University Press.

Swan, M. (1995). Practical English Usage. USA: Oxford University Press.

Taleghani, A. (2008). Modality, Aspect and Negation in Persian. Amsterdam: John Benjamins Publishing Company.

Theft Act (1861). [Online] Available: www.banksr.co.uk/ (June 22, 2012). 
